\title{
Distinct Eras in the History of U.S. Debt Monetization
}

\author{
Paul E. Godek ${ }^{1 *}$ \\ ${ }^{1}$ Navigant Economics, Washington, DC, USA \\ * Paul E. Godek, E-mail: paul.godek@ navigant.com
}

Received: January 10, 2017

Accepted: January 20, 2017

Online Published: January 23, 2017

doi:10.22158/jepf.v3n1p79

URL: http://dx.doi.org/10.22158/jepf.v3n1p79

Why would governments use seignorage to finance their deficits, knowing that continued money creation ultimately leads to inflation? Under normal conditions developed countries rarely use seignorage. ... Heavy reliance on seignorage usually occurs in war-torn or developing countries, in which military or social conditions dictate levels of government spending well above what the country can raise in taxes or borrow from the public (Note 1).

[W]ith a profligate fiscal policy, it is impossible for a monetary authority to sustain low inflation because the inter-temporal government budget then implies that the monetary authority must sooner or later impose a sufficiently large inflation tax to finance the budget (Note 2).

\begin{abstract}
Here I review the history of debt monetization by the Federal Reserve, as well as the relationship between debt monetization and inflation. While it is commonly held that inflation follows from debt monetization, that has not been the case in the U.S., at least not since the Korean War. From the early 1950s through 2007 debt monetization has been modest and steady, while inflation has been highly variable. With the recent financial crisis, debt monetization entered a new era. Since 2008 the magnitude and composition of debt monetization has no precedent. Also unprecedented is the Federal Reserve's ability to suppress inflation despite extensive debt monetization, at least through 2015. Overall, since the creation of the Federal Reserve, the United States has experienced substantial inflation both with and (more commonly) without debt monetization. It remains to be seen if the United States can experience substantial debt monetization without inflation.
\end{abstract}

\section{Keywords}

seignorage, debt monetization, inflation, financial crisis

\section{Introduction}

Seignorage is an ancient word, originally referring to the exclusive power of the sovereign to coin money. Later, seignorage came to indicate the revenue derived from that power. In a modern economy seignorage occurs when the central bank buys-"monetizes"-government debt. Seignorage, or debt 
monetization, has other names: inflation tax, printing money, and, most recently, quantitative easing. Whatever the terminology, when the Federal Reserve buys U.S. Treasury debt, it becomes a source of federal revenue.

Here I examine the history of debt monetization by the Federal Reserve since it came into existence in 1914. I also examine the relationship between debt monetization and inflation. While it is commonly held that inflation follows from debt monetization, that has not been the case in the U.S., at least not since the Korean War. Since the early 1950s (through 2007) debt monetization has been modest and steady, while inflation has been highly variable.

The rate of debt monetization changed dramatically with the recent financial crisis. Indeed, starting in 2008 the magnitude and composition of debt monetization has no precedent in the Federal Reserve's history. Another unprecedented outcome is the ability of the Federal Reserve to suppress inflation despite extensive debt monetization, at least through 2015.

This overview suggests three distinct periods in the history of U.S. debt monetization: a conventional debt-monetization-with-inflation era, encompassing World War II and the Korean War; the inflation-without-debt-monetization era, encompassing most of the years between the Korean War and the financial crisis; and the debt-monetization-without-inflation (so far) era starting with the financial crisis. Overall, the historical review presented here indicates, contrary to conventional wisdom, that debt monetization is neither a necessary nor a sufficient condition for subsequent inflation to occur.

\section{Debt Monetization}

By law the Federal Reserve is not allowed to buy bonds directly from the Treasury. The Federal Reserve can deal directly with the Treasury only to trade the Federal Reserve's mature bonds for an equivalent value of new bonds. Beyond that the Federal Reserve must buy or sell bonds in the secondary market. The Federal Reserve generally refinances (rolls over) all of its maturing debt and returns the interest payments it receives — net of operating expenses—-back to the Treasury (Note 3).

What does the history of debt monetization look like? Let $F_{t}$ represent the Federal Reserve holdings of government debt at time $t$. Net purchases by the Federal Reserve between successive periods can be written as:

$$
\Delta F_{\mathrm{t}}=F_{\mathrm{t}}-F_{\mathrm{t}-1}
$$

It is informative to measure debt monetization relative to national income $(N)$,

$$
\Delta F_{t} / N_{t}
$$

By that measure and with time intervals of one year, the history of debt monetization by the Federal Reserve since 1915, when it first started purchasing U.S. Treasury debt, is depicted in Figure 1 (Note $4)$.

Over its entire history the average value of debt monetization is .4 percent of GDP per year. Debt monetization exceeded 1 percent of GDP for one year during the Great Depression (1932), for three years during World War II (1943-1945), for one year during the Korean War (1951), and in four of the 
last seven years (2009, 2011, 2013, and 2014). Debt “de-monetization", when the Federal Reserve is a net seller of bonds, also occurs. The Federal Reserve de-monetized debt in 21 years in its history, although the amounts have tended to be minor. Debt de-monetization fell below negative 1 percent of GDP only in 2008.

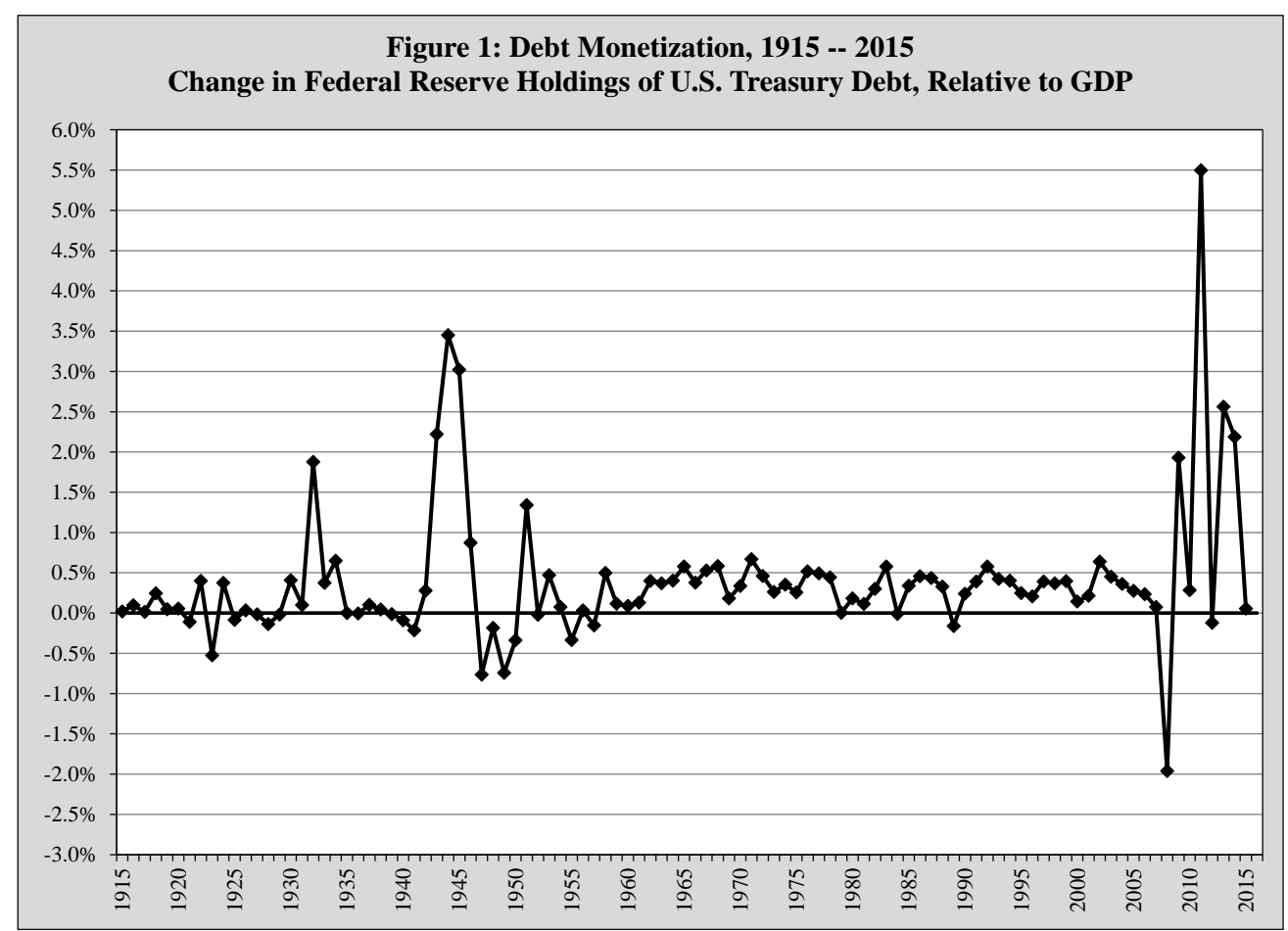

Figure 1. Debt Monetization, 1915-2015

\section{Inflation}

Standard macroeconomic theory indicates that, under fairly broad conditions, inflation $(\pi)$ will be related to debt monetization relative to the money supply $(M)$ :

$$
\pi \approx f(\Delta F / M)
$$

where $f(x)$ represents the relationship between inflation and $\Delta F / M$ (Note 5). Along with the preceding equation, the simple quantity theory of money $(M v=N)$ implies that:

$$
\pi \approx f(\Delta F v / N)
$$

Where $v$ is the velocity of money and $N$ is national income (Note 6). This function represents the conventional view that inflation should be, at least in part, a function of the ratio of Federal Reserve purchases to national income.

The history of debt monetization and inflation in the U.S. since 1940, shown in Figure 2, calls the stability of that function into question (Note 7). While debt monetization at times is correlated with or precedes inflation (see 1943 through 1951, even with the price controls of the 1940s), debt monetization is neither a necessary condition (see 1968 through 1982) nor a sufficient condition (see 2009 through 2015) for contemporaneous or subsequent inflation to occur.

Published by SCHOLINK INC. 


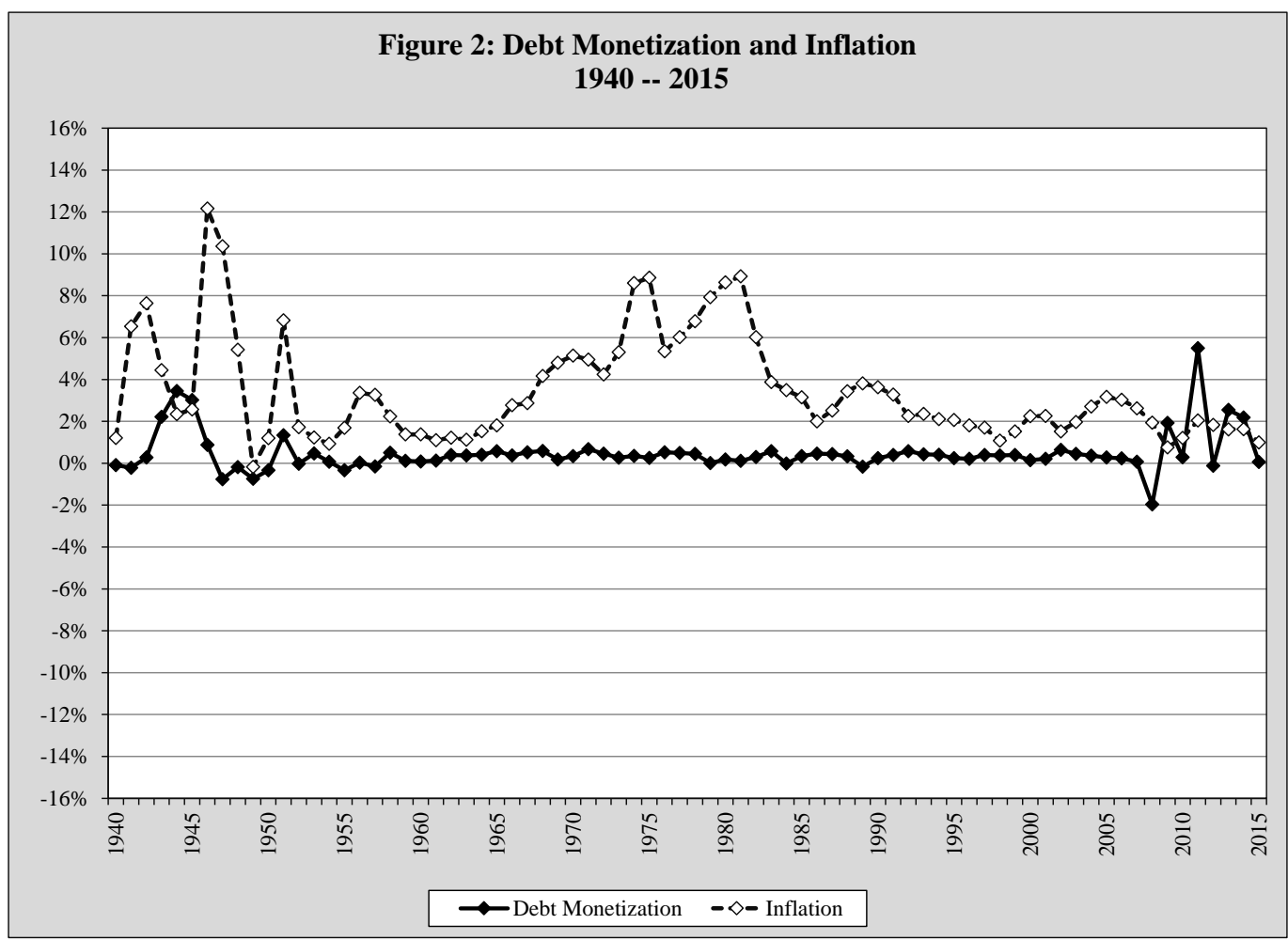

Figure 2. Debt Monetization and Inflation, 1940-2015

From that perspective the more than half-century from 1952 through 2007 is noteworthy. In that period the rate of debt monetization was small and steady, with an average value of .3 percent of GDP. In contrast, over the same period inflation has not only been high, but highly variable as well, exceeding 4 percent for fifteen successive years, 1968 through 1982, and exceeding 8 percent in four of those years. The ascent and descent of inflation throughout this period is an important chapter in American economic history, but that history is unrelated to debt monetization (Note 8).

Table 1 summarizes the debt monetization and inflation rates across the various periods discussed above.

Table 1. Selected Periods

\begin{tabular}{cccc}
\hline Period & Number of Years & $\begin{array}{c}\text { Average Rate of Debt } \\
\text { Monetization }\end{array}$ & $\begin{array}{c}\text { Average Rate of Inflation } \\
1915-2015\end{array}$ \\
101 & $0.4 \%$ & $2.9 \%$ \\
$1943-1951$ & 9 & $1.0 \%$ & $5.0 \%$ \\
$1952-2007$ & 56 & $0.3 \%$ & $3.4 \%$ \\
$1968-1982$ & 15 & $0.3 \%$ & $6.4 \%$ \\
$2009-2015$ & 7 & $1.8 \%$ & $1.4 \%$ \\
\hline
\end{tabular}




\section{Debt Monetization and the Financial Crisis}

The Federal Reserve's response to the recent financial crisis has no precedent. In 2008 the Federal Reserve engineered the largest debt de-monetization in its history, selling about $\$ 300$ billion in U.S. Treasury securities. Federal Reserve sales amounted to more than 2 percent of GDP in that year. This de-monetization was more than offset, however, by the purchase of private debt from banks and non-bank institutions alike. Thus, it appears that the Federal Reserve was selling federal debt in order to offset its purchases of private debt (Note 9). That desire for neutrality did not persist. Between the end of 2008 and the end of 2014, the Federal Reserve set post-World War II records for debt monetization, purchasing about $\$ 1.6$ trillion in Treasury securities, averaging about 2 percent of GDP per year over the five years.

But something else changed as well. In 2008 the Federal Reserve began buying the obligations of so-called Government-Sponsored Enterprises (GSEs). These GSE obligations are referred to in the Federal Reserve balance sheet as "agency securities" and "mortgage-backed securities". Agency securities are conventional bonds issued by the following GSEs: the Federal National Mortgage Association (Fannie Mae), the Federal Home Loan Mortgage Corporation (Freddie Mac), and the Federal Home Loan Bank System (FHLBS) (Note 10). Mortgage-backed securities are those issued by Fannie Mae, Freddie Mac, and another GSE, the Government National Mortgage Association (Ginnie Mae). Federal Reserve holdings of the various types of federal obligations since 2008 are displayed in Figure 3. Table 2 summarizes these values by year.

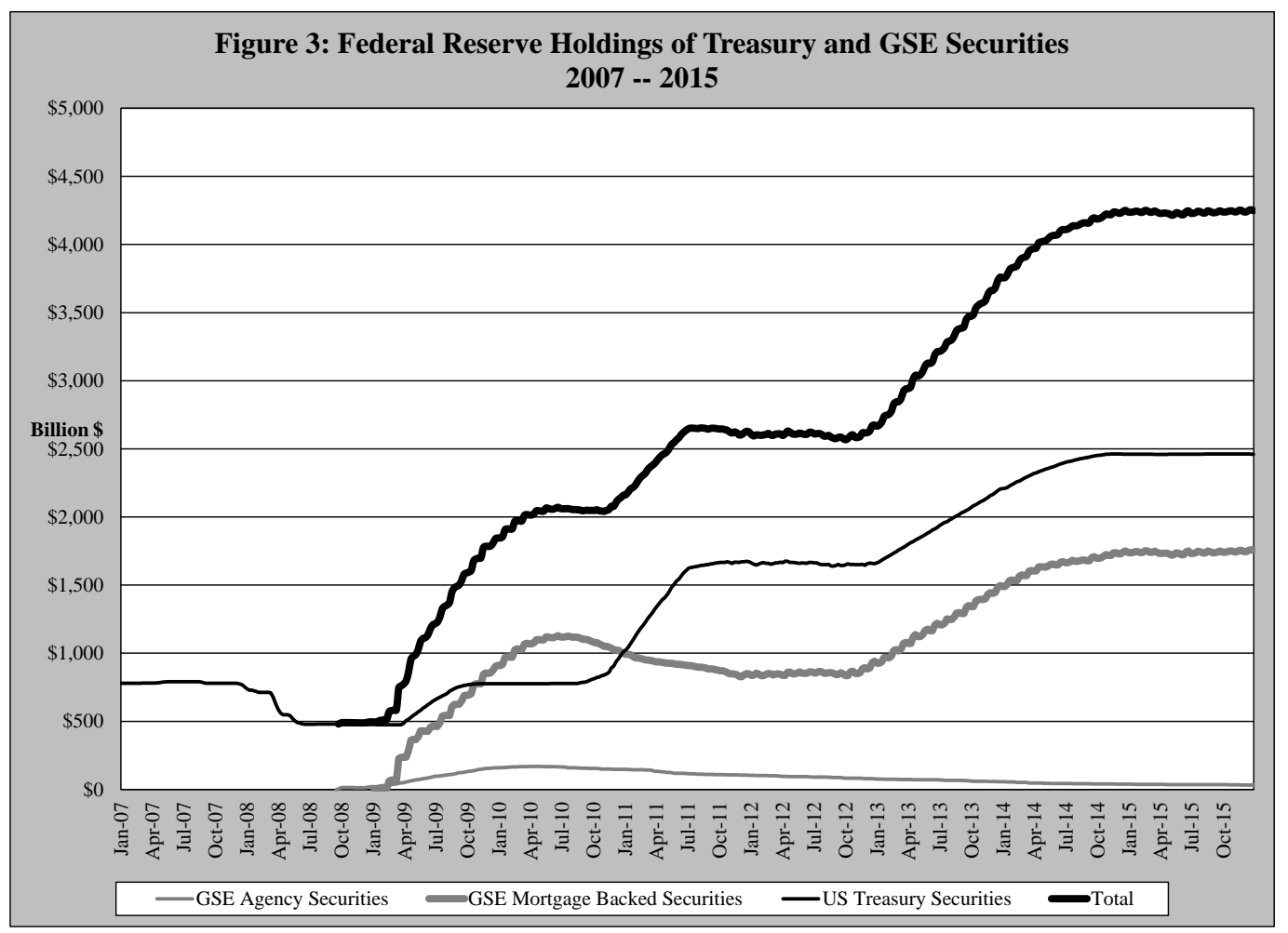

Figure 3. Federal Reserve Holdings of Treasury and GSE Securities, 2007-2015 
Table 2. Federal Reserve Holdings of Treasury and GSE Debt, 2007-2015

\begin{tabular}{|c|c|c|c|c|c|c|c|}
\hline \multirow{4}{*}{$\begin{array}{l}\text { End of } \\
\text { Fiscal } \\
\text { Year }\end{array}$} & \multicolumn{4}{|c|}{ \$ Billions } & \multicolumn{3}{|c|}{ Share of Total } \\
\hline & U.S. & & GSE & & U.S. & GSE & GSE \\
\hline & Treasury & Securities & Mortgage-Backed & Total & Treasury & Agency & Mortgage-Backed \\
\hline & Securities & & Securities & & Securities & Securities & Securities \\
\hline 2007 & $\$ 779.6$ & $\$ 0.0$ & $\$ 0.0$ & $\$ 779.6$ & $100.0 \%$ & $0.0 \%$ & $0.0 \%$ \\
\hline 2008 & $\$ 476.6$ & $\$ 3.7$ & $\$ 0.0$ & $\$ 480.3$ & $99.2 \%$ & $0.8 \%$ & $0.0 \%$ \\
\hline 2009 & $\$ 766.1$ & $\$ 130.1$ & $\$ 692.2$ & $\$ 1,588.4$ & $48.2 \%$ & $8.2 \%$ & $43.6 \%$ \\
\hline 2010 & $\$ 808.9$ & $\$ 154.1$ & $\$ 1,086.2$ & $\$ 2,049.2$ & $39.5 \%$ & $7.5 \%$ & $53.0 \%$ \\
\hline 2011 & $\$ 1,663.6$ & $\$ 108.3$ & $\$ 875.7$ & $\$ 2,647.5$ & $62.8 \%$ & $4.1 \%$ & $33.1 \%$ \\
\hline 2012 & $\$ 1,643.2$ & $\$ 84.8$ & $\$ 847.9$ & $\$ 2,575.8$ & $63.8 \%$ & $3.3 \%$ & $32.9 \%$ \\
\hline 2013 & $\$ 2,056.8$ & $\$ 63.7$ & $\$ 1,349.9$ & $\$ 3,470.4$ & $59.3 \%$ & $1.8 \%$ & $38.9 \%$ \\
\hline 2014 & $\$ 2,447.1$ & $\$ 40.0$ & $\$ 1,708.1$ & $\$ 4,195.2$ & $58.3 \%$ & $1.0 \%$ & $40.7 \%$ \\
\hline 2015 & $\$ 2,461.9$ & $\$ 35.1$ & $\$ 1,742.9$ & $\$ 4,239.9$ & $58.1 \%$ & $0.8 \%$ & $41.1 \%$ \\
\hline
\end{tabular}

The federal guarantee of the obligations of Fannie Mae, Freddie Mac, and FHLBS used to be described as implicit (Ginnie Mae's obligations have always had an explicit guarantee); but with the federal takeover of Fannie Mae and Freddie Mac it became clear that the U.S. Treasury intends to honor all of the GSE obligations (Note 11).

If one views these GSE obligations as federal debt, the implications are dramatic. Table 3 shows the rate of debt monetization - the change in Federal Reserve holdings relative to GDP - based on its acquisition of both Treasury Securities and GSE securities.

Table 3. Debt Monetization Relative to GDP, 2007-2015

\begin{tabular}{ccc}
\hline End of Fiscal Year & Treasury Debt Monetization / GDP & $\begin{array}{c}\text { Treasury + GSE Debt Monetization } \\
\text { / GDP }\end{array}$ \\
\hline 2007 & $0.1 \%$ & $0.1 \%$ \\
2008 & $-2.1 \%$ & $-2.0 \%$ \\
2009 & $2.0 \%$ & $7.7 \%$ \\
2010 & $0.3 \%$ & $3.1 \%$ \\
2011 & $5.5 \%$ & $3.9 \%$ \\
2012 & $-0.1 \%$ & $-0.4 \%$ \\
2013 & $2.5 \%$ & $5.4 \%$ \\
2014 & $2.2 \%$ & $4.2 \%$ \\
2015 & $0.1 \%$ & $0.2 \%$
\end{tabular}


Recall that the highest level of debt monetization prior to the financial crisis occurred in 1944 at 3.5 percent of GDP. Considering both Treasury and GSE debt, for the six years 2009-2014 the average rate of debt monetization was 3.9 percent of GDP - about ten times the historical average to that point. Debt monetization exceeded the World War II peak in four of those six years, with a maximum rate of 7.7 percent in 2009. Another way to appreciate these magnitudes is to note that by the end of 2007 the Federal Reserve over its entire history had acquired on net $\$ 780$ billion of nominal federal debt. Over the next seven years, it would acquire an additional $\$ 3.5$ trillion, more than four times as much as in the previous 92 years.

\section{Excess Reserves and Suppressed Inflation}

Despite this unprecedented debt monetization, inflation has remained low, averaging 1.50 percent over the eight years from 2008 through 2015. Many economists have observed that the broader money supply remains uninflated because of the unprecedented buildup of excess reserves - the deposits of banks with the Federal Reserve in excess of their reserve requirements (Note 12). Excess reserves had been negligible until 2008. They increased from less than $\$ 2$ billion at the beginning of 2007 to a peak of about $\$ 2.7$ trillion by September 2014 . That $\$ 2.7$ trillion is about 80 percent of the $\$ 3.4$ trillion of debt monetization over the same period. Figure 4 shows the history of bank reserves over the last eight years.

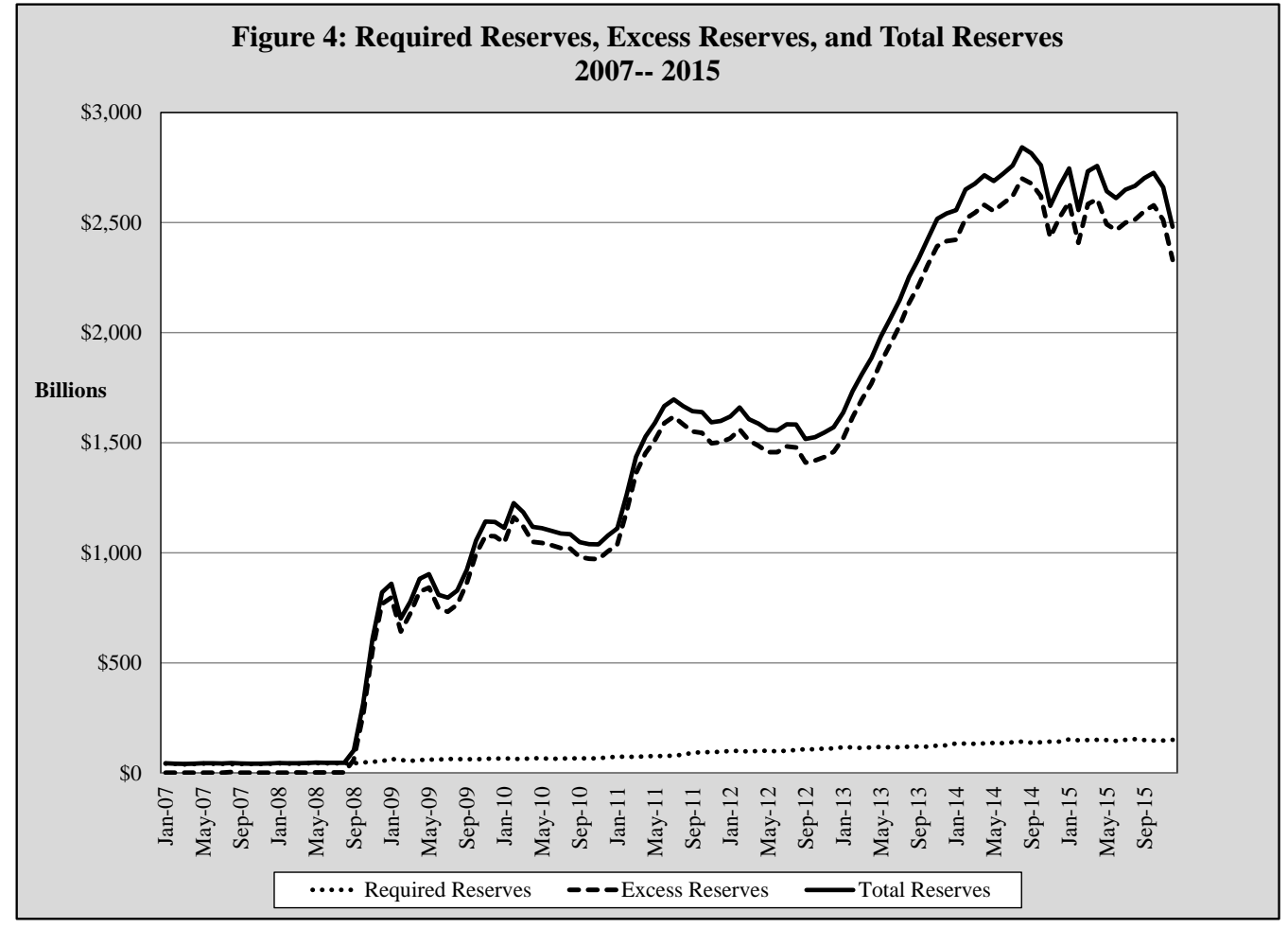

Figure 4. Required Reserves, Excess Reserves, and Total Reserves, 2007-2015 
This build-up of excess reserves followed from the newly-introduced policy of paying interest on those reserves, at about the same rate as short-term treasury bills. The Federal Reserve had not been allowed to pay interest on reserves, until that restriction was lifted by the passage of the Emergency Economic Stabilization Act of 2008 (Note 13).

So, while the Federal Reserve is printing money, the banks are keeping most of that money on deposit with the Federal Reserve. Another unprecedented outcome: while annual inflation rates have averaged 1.50 percent over the last eight years, one-year Treasury bill rates have averaged .44 percent. Since the financial crisis, the U.S. government has been borrowing money, at least short-term, at negative real rates of interest.

\section{Conclusion}

Several observations follow from this review of the history of debt monetization in the United States:

- Debt monetization, resulting in substantial inflation, played a role in financing World War II and the Korean War. This might be described as the conventional era in the history of U.S. debt monetization.

- From the early 1950s through the end of 2007, debt monetization served as a steady and minor source of federal revenue, accounting for less than $1 / 3^{\text {rd }}$ of 1 percent of GDP and less than 2 percent of federal spending. It follows that the high rates of inflation in the 1970s and 1980s did not occur as a result of government finance through debt monetization.

- The period since 2008 is unlike any other in the Federal Reserve's history, not only because of the unprecedented levels of debt monetization, but also because U.S. Treasury debt has been joined with GSE debt as another conduit for debt monetization. As this most recent period continues, it remains to be seen whether the Federal Reserve can prevent the inflation implied and so far delayed.

In sum, since creation of the Federal Reserve, the United States has experienced substantial inflation both with and (more commonly) without debt monetization. It remains to be seen if the United States can experience substantial debt monetization without inflation.

\section{Acknowledgements}

For helpful comments, the author thanks without implicating Serdar Dalkir, Mark Fisher, Ilan Guedj, Todd Hasson, Craig McCann, Carmen Taveras, and Walter Thurman.

\section{References}

Abel, A. B., \& Bernanke, B. S. (2005). Macroeconomics (5th ed.). Pearson Addison Wesley. Akhtar, M. A. (1997). Understanding Open Market Operations. Federal Reserve Bank of New York. Andolfatto, D., \& Li. (2013). Is the Fed Monetizing Government Debt? Federal Reserve Bank of St. Louis Economic Synopses, 5.

Catão, L. A. V., \& Terrones, M. E. (2005). Fiscal deficits and inflation. Journal of Monetary Economics, Published by SCHOLINK INC. 
52(3), 529-554. https://dx.doi.org/10.1016/j.jmoneco.2004.06.003

Cecchetti, S. G. (2009, Winter). Crisis and Responses: The Federal Reserve in the Early Stages of the Financial Crisis. Journal of Economic Perspectives, 51-75. https://dx.doi.org/10.1257/jep.23.1.51

Dornbusch, R., \& Fisher, S. (1993). Moderate Inflation. World Bank Economic Review, 7(1), 1-44. https://dx.doi.org/10.1093/wber/7.1.1

Fabozzi, F. J. (Ed.). (2012). The Handbook of Fixed Income Securities (8th ed.). McGraw-Hill.

Federal Reserve Bank of San Francisco. (2013, March). Why did the Federal Reserve start paying interest on reserve balances held on deposit at the Fed? Retrieved from http://www.frbsf.org

Flannery, M. J., \& Frame, W. S. (2006). The Federal Home Loan Bank System: The “Other” Housing GSE. Federal Reserve Bank of Atlanta Economic Review, 33-54.

Friedman, M. (1971, July-August). Government Revenue from Inflation. Journal of Political Economy, 846-856. https://dx.doi.org/10.1086/259791

Friedman, M., \& Schwartz, A. J. (1963). A Monetary History of the United States, 1867-1960. Princeton University Press.

Ihrig, J. E., Meade, E. E., \& Weinbach, G. C. (2015, Fall). Rewriting Monetary Policy 101: What's the Fed's Preferred Post-Crisis Approach to Raising Interest Rates? Journal of Economic Perspectives, 177-198. https://dx.doi.org/10.1257/jep.29.4.177

Kishor, N. K., \& Kochin, L. A., (2007, January). The Success of the Federal Reserve and the Death of Monetarism. Economic Inquiry, 56-70. https://dx.doi.org/10.1111/j.1465-7295.2006.00005.x

Passmore, W. (2005, September). The GSE Implicit Subsidy and the Value of Government Ambiguity. Real Estate Economics, 465-486. https://dx.doi.org/10.1111/j.1540-6229.2005.00126.x

Plosser, C. (2014, January). Perspectives on the Economy and Monetary Policy. Speech at La Salle University. Retrieved from http://www.phil.frb.org

Sargent, T. J. (1999). The Conquest of American Inflation. Princeton University Press.

Sargent, T. J., (2012, February). Nobel Lecture: United States Then, Europe Now.. Journal of Political Economy, 120(1), 1-40. https://dx.doi.org/10.1086/665415

Sargent, T. J. \& Surico, P. (2011, February). Two Illustrations of the Quantity Theory of Money: Breakdowns and Revivals. American Economic Review, 109-128.

Sargent, T. J. \& Wallace, N. (1981). Some Unpleasant Monetarist Arithmetic. Federal Reserve Bank of Minneapolis Quarterly Review, 1-17.

Thornton, D. L. (2010). Monetizing the Debt. Federal Reserve Bank of St. Louis Economic Synopses, 14.

Williamson, S. D. (2015). Monetary Policy Normalization in the United States. Federal Reserve Bank of St. Louis Review, 97(2), 87-108.

Williamson, S. H. (n.d.). Measuring Worth. Retrieved from http://www.measuringworth.com 


\section{Notes}

Note 1. Abel and Bernanke (2005, p. 591).

Note 2. Sargent (2012, p. 28).

Note 3. For a detailed description of Federal Reserve operating procedures, see Akhtar (1997) and Fabozzi (2012).

Note 4. The sources for all of the data used in this paper are described in detail in Appendix B. Annual figures for all Federal Reserve data are on a fiscal-year basis. GDP and the GDP deflator are on a calendar-year basis.

Note 5. See Friedman (1971), Sargent and Wallace (1981), Dornbusch and Fisher (1993), and Abel and Bernanke (2005, chapters 14 and 15).

Note 6 . The basic quantity-theory identity is employed only to illustrate the simplest version of the relationship, not to suggest that velocity is stable or that the function is time-invariant. I am aware of no attempt to estimate an empirical relationship between inflation and debt-monetization for the U.S. The results here do not suggest that such an effort would be productive. Though see Catão and Terrones (2005) on the relationship between fiscal deficits and inflation.

Note 7. While the previous section looks at the entire history of the Federal Reserve, this section looks at inflation since 1940. Wide swings in the GDP deflator, both positive and negative, that occurred before 1940 are clearly unrelated to debt monetization. See Friedman and Schwartz (1963, chapters 5-9). Inflation is measured as the natural logarithm of the ratio of successive values of the GDP deflator.

Note 8. Debt monetization as defined here is equivalent to the textbook definition of net open-market operations, which are widely understood to be a primary tool of the monetary authorities. Given that inflation in the U.S. bears no relationship to debt monetization, at least since 1952, open-market operations by themselves do not seem to play a meaningful role in how the Federal Reserve controls inflation. How the Federal Reserve does control inflation is not further addressed here. Sargent (1999) provides a comprehensive treatment of that topic. See also Kishor and Kochin (2007), Sargent and Surico (2011), Sargent (2012), and Ihrig et al. (2015).

Note 9. The values for the private debt held by the Federal Reserve since 2007 are shown in Appendix A. Most of the private debt purchased during the financial crisis would be sold by the end of 2012 . Private debt would seem to play a different role in the Federal Reserve's balance sheet. Even though substantial profits or losses may occur on the Federal Reserve's purchases of private debt, there is no presumption that these private obligations would be forgiven or rolled over indefinitely. See Williamson (2015) for a concise overview of Federal Reserve policy since the financial crisis.

Note 10. See Flannery and Frame (2006) for a succinct discussion of the various GSEs. As with Treasury securities, GSE securities are shown at face value.

Note 11. See Fabozzi (2012, Chapter 10) and Passmore (2005) for discussions of the federal guarantee of GSE securities. Given the bankruptcy and federal takeover of Fannie Mae and Freddie Mac, their 
agency securities would be worthless without the federal guarantee. The mortgage backed securities, on the other hand, might retain substantial value even without any federal guarantee, to the extent that they are serviced by the underlying mortgages.

Note 12. See Thornton (2010), Andolfatto and Li (2013), Plosser (2014), Ihrig et al. (2015).

Note 13. For details see Federal Reserve Bank of San Francisco (2013).

\section{Appendix A}

\section{Federal Reserve Holdings of Private Debt}

Table 4 shows Federal Reserve holdings of private debt over the period 2007 through 2015.

Table 4. Federal Reserve Holdings of Private Debt in \$ Billions, 2007-2015

\begin{tabular}{ccccc}
\hline $\begin{array}{c}\text { End of Fiscal } \\
\text { Year }\end{array}$ & $\begin{array}{c}\text { All Liquidity } \\
\text { Facilities }\end{array}$ & $\begin{array}{c}\text { Support for Specific } \\
\text { Institutions }\end{array}$ & $\begin{array}{c}\text { Total Private } \\
\text { Debt }\end{array}$ & $\begin{array}{c}\text { Change in Total } \\
\text { Private Debt }\end{array}$ \\
\hline 2007 & $\$ 0.2$ & $\$ 0.0$ & $\$ 0.2$ & - \\
2008 & $\$ 509.7$ & $\$ 74.0$ & $\$ 583.6$ & $\$ 583.4$ \\
2009 & $\$ 347.8$ & $\$ 100.3$ & $\$ 448.1$ & $-\$ 135.6$ \\
2010 & $\$ 30.9$ & $\$ 112.0$ & $\$ 143.0$ & $-\$ 305.1$ \\
2011 & $\$ 12.0$ & $\$ 46.7$ & $\$ 58.6$ & $-\$ 84.3$ \\
2012 & $\$ 16.4$ & $\$ 1.8$ & $\$ 18.2$ & $-\$ 40.4$ \\
2013 & $\$ 0.5$ & $\$ 1.6$ & $\$ 2.1$ & $-\$ 16.1$ \\
2014 & $\$ 0.4$ & $\$ 1.7$ & $\$ 2.0$ & $-\$ 0.1$ \\
2015 & $\$ 0.9$ & $\$ 1.7$ & $\$ 2.6$ & $\$ 0.6$ \\
\hline
\end{tabular}

The Federal Reserve describes these holdings as follows:

All Liquidity Facilities includes: term auction credit; primary credit; secondary credit; seasonal credit; primary dealer credit facility; asset-backed commercial paper money market mutual fund liquidity facility; term asset-backed securities loan facility; commercial paper funding facility; and central bank liquidity swaps.

Support to Specific Institutions includes: Maiden Lane LLC; Maiden Lane II LLC; Maiden Lane III LLC; and support to AIG.

The "Maiden Lane" entities were established to acquire and service AIG and Bear Sterns debt.

\section{Appendix B}

\section{Data Sources}

- $\quad$ Federal Reserve holdings of Treasury securities from 1940 are from the Office of Management and Budget (http://www.whitehouse.gov/omb/budget/historicals), Table 7.1. Data before 1940 are from 
the Annual Report of the Secretary of the Treasury, 1942, Table 99.C.

- GDP values from 1929 are from the Department of Commerce: Bureau of Economic Analysis (http://www.bea.gov/national/index.htm\#gdp). GDP values from 1914 to 1928 are from "Measuring Worth" (http://www.measuringworth.com).

- GDP deflator values from 1929 forward are from the Department of Commerce, Bureau of Economic Analysis (http://www.bea.gov/national/index.htm\#gdp). GDP deflator values from 1914 to 1928 are from "Measuring Worth" (http://www.measuringworth.com).

- Federal Reserve holdings of all Treasury and GSE securities for the period since 2008 are from the Federal Reserve Statistical Release H41: Factors Affecting Reserve Balances (http://www.federalreserve.gov/releases/h41/hist/h41hist3.htm).

- Federal Reserve holdings of all private debt for the period since 2007 are from the Federal Reserve (http://www.federalreserve.gov/monetarypolicy/bst_recenttrends.htm), under "Selected Assets of the Federal Reserve".

- $\quad$ Excess reserves and Treasury bill rates are from the St. Louis Federal Reserve FRED data base. 